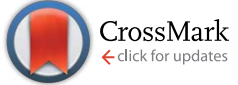

Cite this: RSC Adv., 2015, 5, 96222

Received 17th September 2015 Accepted 2nd November 2015

DOI: $10.1039 / \mathrm{c} 5 \mathrm{ra19192k}$

www.rsc.org/advances

\section{Synthesis of a new class of naphthoquinone glycoconjugates and evaluation of their potential as antitumoral agents $\dagger$}

\author{
Vinicius R. Campos, ${ }^{a}$ Anna C. Cunha, ${ }^{\text {*a }}$ Wanderson A. Silva, ${ }^{a}$ Vitor F. Ferreira, ${ }^{a}$ \\ Carla Santos de Sousa, ${ }^{\mathrm{b}}$ Patrícia D. Fernandes, ${ }^{\mathrm{b}}$ Vinícius N. Moreira, ${ }^{a}$ David R. da \\ Rocha, ${ }^{a}$ Flaviana R. F. Dias, ${ }^{a}$ Raquel C. Montenegro, ${ }^{c}$ Maria C. B. V. de Souza, ${ }^{a}$ \\ Fernanda da C. S. Boechat, ${ }^{a}$ Caroline F. J. Franco ${ }^{a}$ and Jackson A. L. C. Resende ${ }^{d}$
}

\begin{abstract}
A novel series of carbohydrate-based naphthoquinones was synthesized and evaluated for cytotoxicity against different cancer cell lines. The compounds derived from 5-hydroxy-1,4-naphthoquinone (juglone) showed better cytotoxicity profiles against HCT-116, A-549 and MDA-MB 435 human cancer cells than the parent compound. The results suggest that the hydroxyl group on the aromatic ring increased the pro-oxidant activity of these new naphthoquinone derivatives. Furthermore, two derivatives were found to be more active against melanoma cells (MDA-MB435) than the clinically useful anticancer agent doxorubicin, and none of the compounds caused mouse erythrocyte lysis.
\end{abstract}

\section{Introduction}

Natural glycoconjugated compounds, ${ }^{1-3}$ 1-7 (Fig. 1), are useful drugs that are commonly used clinically in the treatment of cancer. The importance of the carbohydrate residues in these structures has been well established: these moieties are important for solubilization and also decrease the toxicity and improve the pharmacokinetics of the compounds. ${ }^{4}$ Indeed, several cases in the literature ${ }^{5}$ show the benefit to biological activity of a carbohydrate moiety in the structure of a molecule. For example, the sugar moieties in antibiotic anthracycline derivatives 1-3 (Fig. 1) participate in the molecular recognition of the main cellular targets, DNA and topoisomerase II, forming a DNA-drug-topoisomerase II ternary complex in which the enzyme is covalently linked to a broken DNA strand, which is critical for the induction of apoptosis and cell death. ${ }^{6,7}$

Other mechanisms can be involved in quinone toxicity of such as redox cycles, which result in the production of semiquinone radicals and reactive oxygen species (ROS). These

${ }^{a}$ Universidade Federal Fluminense, Departamento de Química Orgânica, Programa de Pós-Graduação em Química, Outeiro de São João Batista, 24020-141 Niterói, RJ, Brazil. E-mail: annac@vm.uff.br; Fax: +55 21 26292145; Tel: +55 2126292148

${ }^{b}$ Universidade Federal do Rio de Janeiro, Instituto de Ciências Biomédicas, Laboratório de Farmacologia da Dor e da Inflamação, CCS, Bloco J, sala 10. Cidade Universitária, RJ, Brazil

'Universidade Federal do Pará, Instituto de Ciências Biológicas, Belém, PA, Brazil

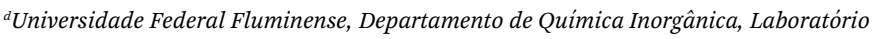
Regional de Difração de Raios X (LDRX), 24020-141, Niterói, RJ, Brazil

$\dagger$ Electronic supplementary information (ESI) available. CCDC 1055524 and 1055525. For ESI and crystallographic data in CIF or other electronic format see DOI: $10.1039 / \mathrm{c} 5 \mathrm{ra} 19192 \mathrm{k}$ events lead to the depletion of glutathione in cells as well as damage to other intracellular components. ${ }^{3}$

The importance of exploring the synthesis of sugar-conjugated compounds to increase the selectivity of drug uptake is based on the Warburg effect, ${ }^{8}$ which is related to the large consumption of glucose by cancerous cells compared to normal cells due to the high rate of aerobic glycolysis in the former. ${ }^{8}$

Recently, our group described the synthesis and pharmacological evaluation of a series of carbohydrate-based quinones. In this study, ${ }^{5}$ compounds $8 \mathbf{8}$ and $\mathbf{8 b}$ (Fig. 2) ( IC $_{50}$ below $3.0 \mu \mathrm{M}$ ) were found to exhibit significant activity against a melanoma cell line (MDA-MB 435).

Quinones containing heterocyclic aromatic rings in their structures have been extensively explored by many research groups., ${ }^{9,10}$ Structure-activity relationship studies have revealed that the number and position of nitrogen $(\mathrm{N})$ atoms in the fiveor six-membered heterocyclic ring are critical factors for enhancing antitumor activity.,

Among nitrogen-containing heterocycles, 1,2,3-triazole derivatives exhibit a broad spectrum of biological properties ${ }^{\mathbf{1 1 - 1 5}}$ and may serve as scaffold structures for the development of new pharmaceutical compounds. This heterocyclic system is resistant to metabolic degradation and can interact with biological targets through hydrogen bonds and dipole interactions, properties that may be responsible for the enhanced biological activities of many synthetically versatile molecules. ${ }^{16}$

To extend our investigation into the synthesis and biological evaluation of quinone glycoconjugate compounds ${ }^{5,17}$ and 1,2,3triazole derivatives, ${ }^{\mathbf{1 1 - 1 5}}$ we prepared a new series of naphthotriazoles, 9a-c (Scheme 1), and assessed their activity against three types of cancer cells: human colorectal carcinoma 


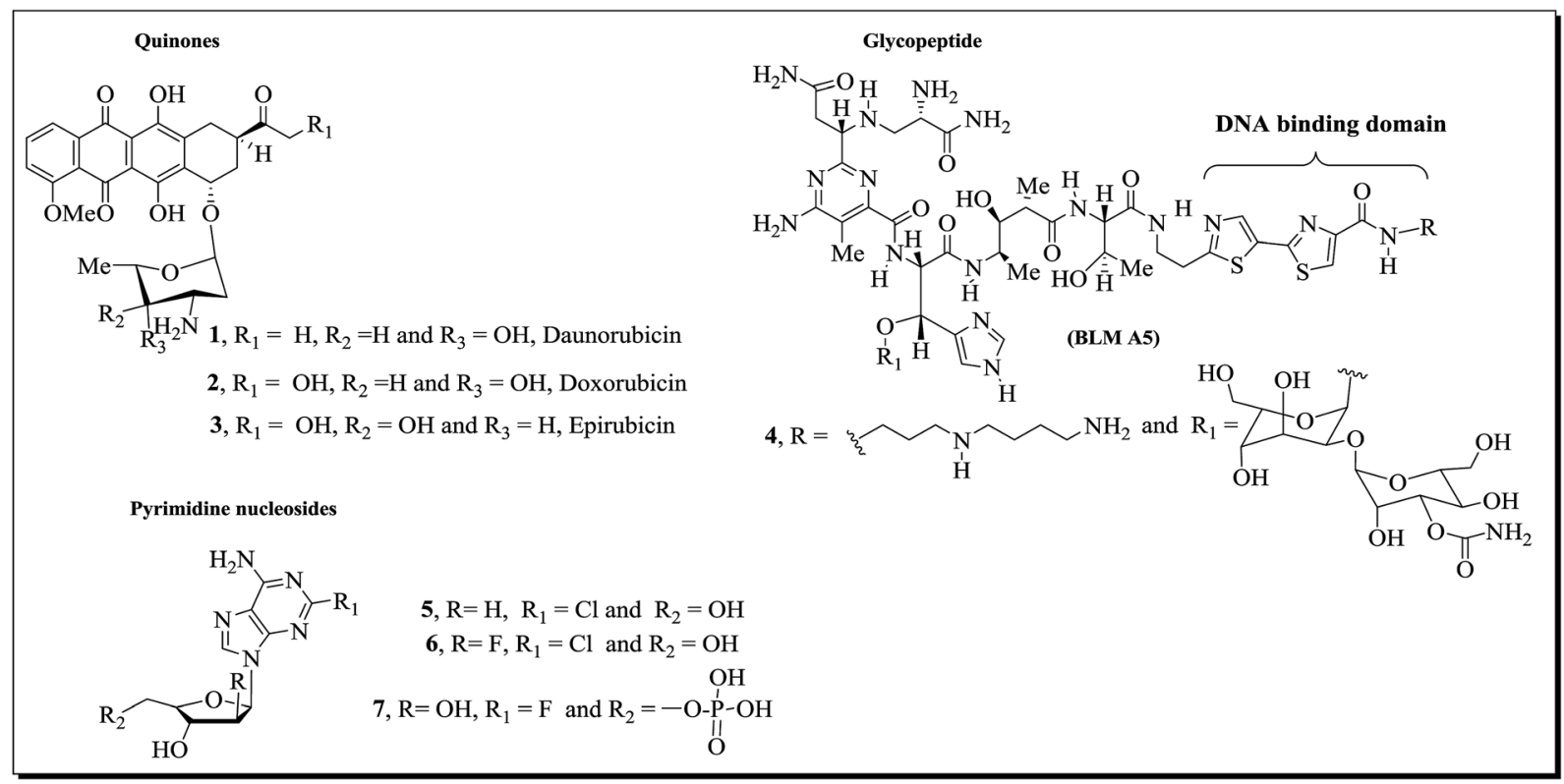

Fig. 1 Examples of natural glycoconjugated compounds (1-7) with antitumoral activity.

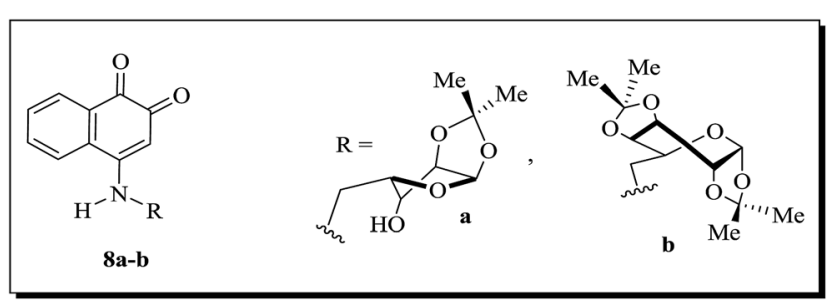

Fig. 2 Examples of synthetic molecules ( $8 a$ and $8 b$ ) with antitumoral activities.

(HCT-116), human lung adenocarcinoma (A-549) and human melanoma (MDA-MB435).

The synthesis of derivatives ${ }^{\mathbf{1 7}} \mathbf{1 0 a}-\mathbf{c}$, which possess aminocarbohydrate chains at the $\mathrm{C}-2$ position of the quinone moiety (Scheme 1), was also performed to verify the possible pharmacophoric effects of the 1,2,3-triazole moiety fused to naphthoquinone.
Naturally occurring hydroxy naphthoquinone (juglone, 12) exhibits a toxicological effect through its ability to undergo redox cycling to damage macromolecules, such as DNA, lipids and proteins. ${ }^{18}$ Several studies have shown that the introduction of a hydroxyl group at the carbon of the benzene moiety improves the pro-oxidant properties of naphthoquinone derivatives, stimulating lipid peroxidation and adduct formation with macromolecules. ${ }^{18}$

Based on these reports, we also decided to prepare a new series of hydroxylated naphthoquinones, 11a-c, exploring cycloaddition between juglone (12) and azide-functionalized carbohydrates 13a-c (Scheme 1), and to investigate the influence on biological activity of a hydroxyl group at position 5 of the benzene ring.

The compounds 10a-c and 11a-c were also evaluated for their cytotoxic activities against cancer cell lines HCT-116, A-549 and MDA-MB435.

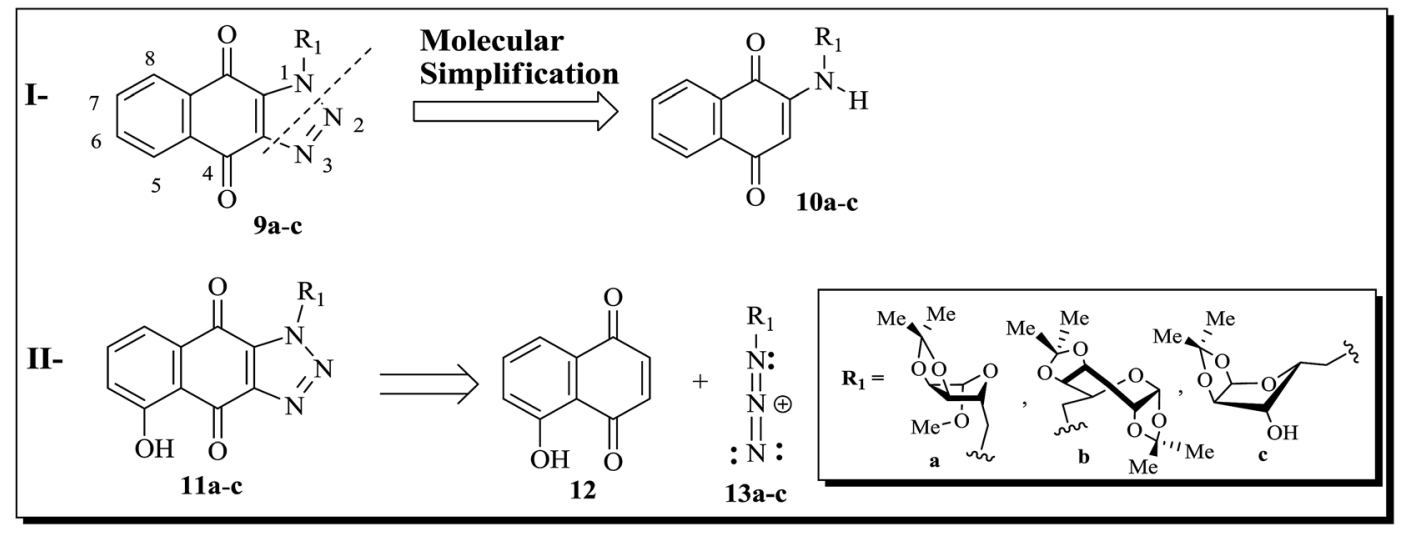

Scheme 1 Strategy for the synthesis of naphthoquinone derivatives $9 a-c, 10 a-c$ and $11 a-c$. 


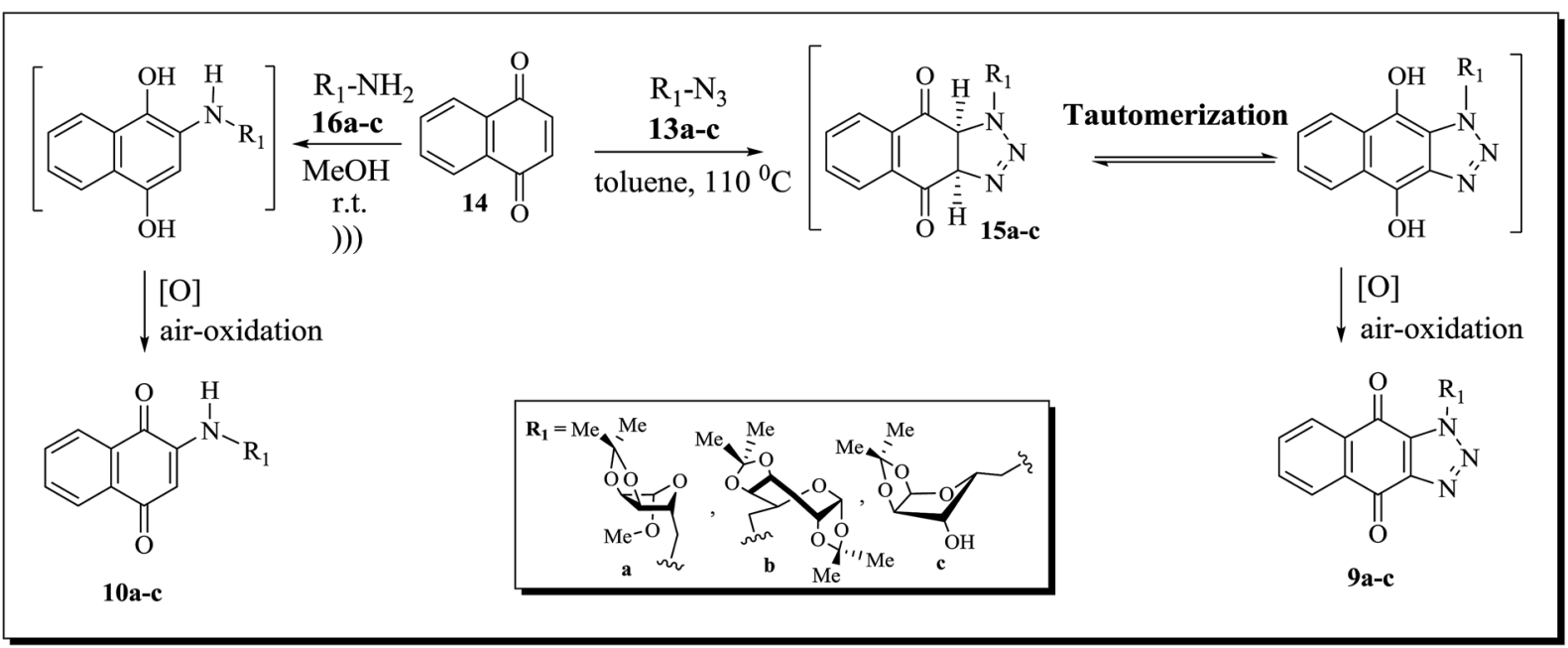

Scheme 2 Synthesis of the novel naphthotriazole derivatives $9 a-c$ and 2 -aminonaphthoquinones $10 a-c$.

\section{Results and discussion}

\subsection{Chemistry}

Naphthotriazole derivatives 9a-c (Scheme 2) were obtained in moderate yields via a $[3+2]$ cycloaddition reaction between glycosyl azides 13a-c and 1,4-naphthoquinone (14) (Scheme 2). The probable mechanism for the formation of these compounds involves an initial 1,3-dipolar cycloaddition reaction between the azide carbohydrates 13a-c and 1,4-benzoquinone (14), producing the corresponding triazoline intermediates $\mathbf{1 5 a}-\mathbf{c}$, which are tautomerized and oxidized to form the desired glycotriazole derivatives $\mathbf{9 a - c .}$

Glycosyl azides 13a-c were prepared from their corresponding commercially available reagents D-ribose, D-xylose and $\mathrm{D}^{-}$ galactose using previously described methods for carbohydrate derivatization $^{\mathbf{1 9 2 0}}$ (Scheme 3).

The aminonaphthoquinone analogs 10a-c (Scheme 2) were synthesized in moderate yields via ultrasound-accelerated 1,4cycloaddition between 1,4-naphthoquinone (14) and different aminocarbohydrates (16a-c), according to our previous report. ${ }^{17}$ Reduction of the azide derivatives 13a-c in the presence of a catalytic amount of $10 \% \mathrm{Pd} / \mathrm{C}$ (Scheme 3 ) led to the corresponding amines 16a-c.

Juglone 12, prepared in $85 \%$ yield via the methodology described by Ferreira and coworkers, ${ }^{21}$ was reacted with azide compounds 13a and 13b. Although it is possible to form a mixture of the 5- and 8-hydroxy-naphthotriazole regioisomers (Scheme 4) via this thermal 1,3-dipolar cycloaddition reaction, only 5 -hydroxy-1-substituted- $1 H$-naphtho[2,3- $d][1,2,3$-] triazole4,9-dione derivatives 11a and 11b were isolated, in moderate yields. Furthermore, unexpected products $22 \mathbf{a}$ and $\mathbf{2 2 b}$, possessing a carbohydrate chain at the $\mathrm{C}-2$ position of the quinone ring, were also isolated.

The reaction of compound $\mathbf{1 3 c}$ with juglone (12) gave a crude product which upon TLC analysis showed to be a mixture of two major compounds with retention factors $\left(R_{\mathrm{f}}\right)$ very similar. The ${ }^{1} \mathrm{H}$ NMR spectrum of this mixture led to the conclusion that one of the substances corresponded to 11c, the desired compound, and that the other substance was the amine 22c. Attempts to separate the products by chromatography on silica gel column were unsuccessful (Scheme 5).

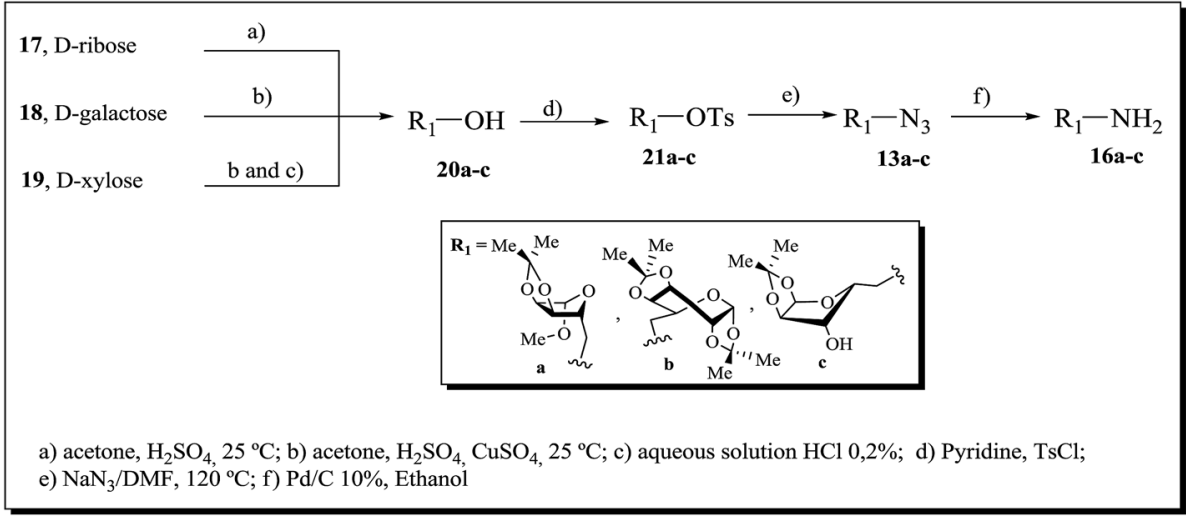

Scheme 3 Preparation of derivatives of carbohydrates $13 a-c$ and $16 a-c$. 


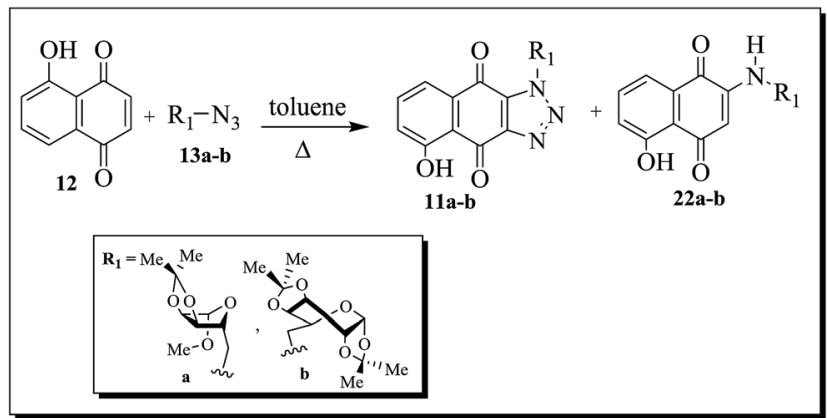

Scheme 4 Preparation of isomeric glycotriazole derivatives 11a and $\mathrm{b}$ and aminonaphthoquinone derivatives $22 \mathrm{a}$ and $\mathrm{b}$.

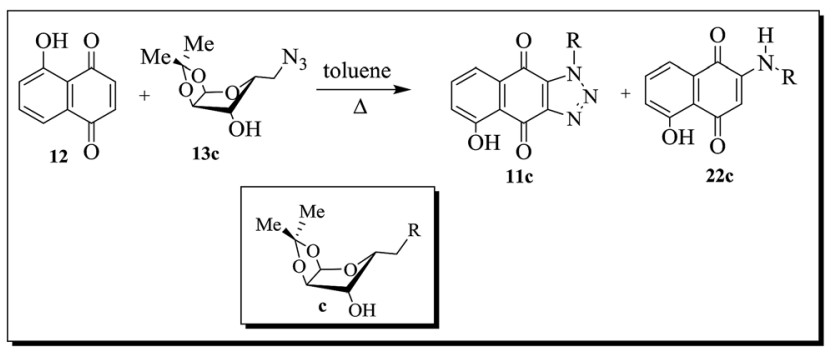

Scheme 5 Synthesis of naphthoquinone compounds $11 \mathrm{c}$ and $22 \mathrm{c}$

The structures of the new compounds 9a-c, 11a, 11b, 22a and 22b were established by spectral data: one- and twodimensional ${ }^{1} \mathrm{H}$ and ${ }^{13} \mathrm{C}$ NMR spectra $\left[{ }^{1} \mathrm{H},{ }^{13} \mathrm{C}-\mathrm{APT}\right.$, COSY- ${ }^{1} \mathrm{H}$ $\times{ }^{1} \mathrm{H}, \mathrm{HSQC}$ and HMBC], IR and elemental analysis.

The ${ }^{1} \mathrm{H}$ NMR spectra of 11a, 11b, 22a and 22b indicate that only one of the two possible isomers was formed. The regiochemistry of the reaction was investigated based on X-ray crystallographic analysis of substances 11a and 22a (Fig. 3). Fig. 3 shows the ORTEP diagrams of these compounds, and crystal data and refinements are provided in Table 2. The diagram shows that the carbohydrate chains are in the anti-position to the hydroxyl group attached to the quinone ring of 11a and 22a. The carbohydrate moieties of 11a and 22a adopt envelope and twist conformations, respectively.

\subsection{Biological assay}

Compounds 9a-c, 10a-c, 11a, 11b, 12, 14, 22a and 22b were tested in vitro against three cancer cell lines and normal cells, human blood peripheral leukocytes, using the MTT assay. Doxorubicin was used as the positive control. Erythrocyte lysis was evaluated at a concentration of $200 \mu \mathrm{M}$. The concentrations inducing $50 \%$ inhibition of cell growth $\left(\mathrm{IC}_{50}\right)$ are reported in Table 2. The compounds were classified according to their activity as highly active ( $\left.\mathrm{IC}_{50}<2 \mu \mathrm{M}\right)$, moderately active $(2 \mu \mathrm{M}<$ $\left.\mathrm{IC}_{50}<10 \mu \mathrm{M}\right)$, or inactive $\left(\mathrm{IC}_{50}>10 \mu \mathrm{M}\right) .^{22}$

The naphthoquinone derivatives 9a-c, 10a-c, 11a, 11b, 12, 14, 22a and 22b (Table 2) did not exhibit a lytic effect against either erythrocytes or normal human leukocytes.

Among naphthotriazoles 9a-c, only derivative 9b showed significant activity against HCT-116 cells, with an $\mathrm{IC}_{50}$ value of $4.85 \mu \mathrm{M}$. This result indicates that the presence of the glycol 1,2,3-triazole subunit determines the biological activity assessed. Aminoquinones $\mathbf{1 0 a}-\mathbf{c}$ showed no activity against the three cell lines, allowing us to speculate that the presence of the amino group attached to carbon 2 has no effect on the biological activity of the compounds.

Aminoquinone analogs 22a and 22b showed higher cytotoxic activities than compounds $10 \mathrm{a}$ and $\mathbf{1 0 b}$. This can be attributed to the presence of the hydroxyl group connected to the benzene ring in these derivatives, possibly contributing to their prooxidant activities. ${ }^{18}$

In addition, the new glycoconjugate compounds $22 \mathbf{a}$ and $22 \mathbf{b}$ were also more active than juglone (12). We speculate that cellular permeability of these 5-hydroxy-1,4-naphthoquinonic derivatives could be improved by the presence of the carbohydrate chain at the C-2 position of the quinone moiety. As 22a and $\mathbf{2 2 b}$ were active against different cell lines, it appears that they can bind to different targets in a specific background.

The series of quinones 11a-c displayed greater activity in all tested cancer cell lines than naphthoquinone derivatives 9a and 9b, possibly indicating that these quinones have increased prooxidant capacity. One can speculate that the hydroxyl attached to the C5 carbon in these derivatives is responsible for their increased anti-tumor activity.
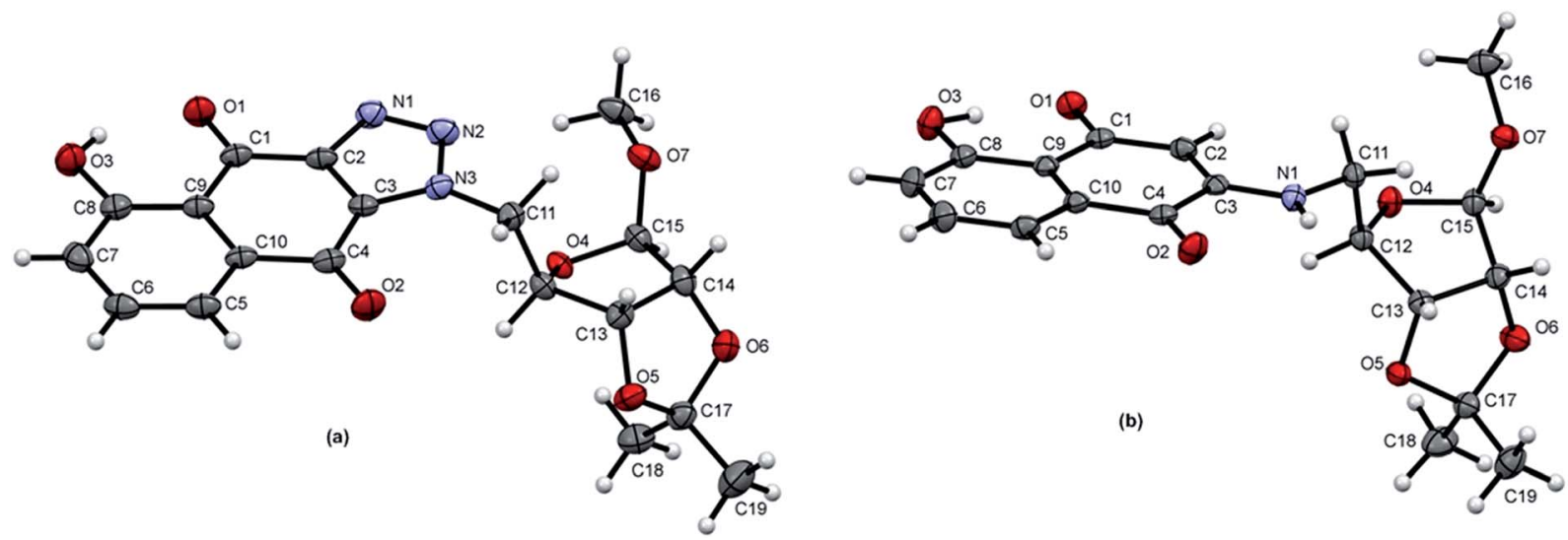

Fig. 3 ORTEP diagrams of compounds $11 \mathrm{a}$ (a) and 22a (b), showing 50\% probability ellipsoids and the atom-numbering scheme. 
Table 1 X-ray crystallographic data for compounds $11 \mathrm{a}$ and 22a

\begin{tabular}{|c|c|c|}
\hline & $11 a$ & $22 a$ \\
\hline Chemical formula & $\mathrm{C}_{19} \mathrm{H}_{19} \mathrm{~N}_{3} \mathrm{O}_{7}$ & $\mathrm{C}_{19} \mathrm{H}_{21} \mathrm{NO}_{7}$ \\
\hline$M_{\mathrm{r}}$ & 401.37 & 375.37 \\
\hline Crystal size/mm & $\begin{array}{l}0.44 \times 0.19 \times \\
0.07 \mathrm{~mm}\end{array}$ & $\begin{array}{l}0.43 \times 0.33 \times \\
0.21 \mathrm{~mm}\end{array}$ \\
\hline Crystal color, habit & Yellow, plate & Yellow, prism \\
\hline $\begin{array}{l}\text { Crystal system, } \\
\text { space group }\end{array}$ & Monoclinic, $P 2_{1}$ & Monoclinic, $P 2_{1}$ \\
\hline Temperature (K) & 150 & 150 \\
\hline$a, b, c(\AA)$ & $\begin{array}{l}5.9539(2), \\
5.7856(2), \\
25.9610(11)\end{array}$ & $\begin{array}{l}5.8376(2), \\
11.9174(4), \\
12.2331(5)\end{array}$ \\
\hline$\beta\left({ }^{\circ}\right)$ & $91.139(4)$ & $94.745(4)$ \\
\hline$V\left(\AA^{3}\right)$ & $894.10(6)$ & $848.13(5)$ \\
\hline$Z$ & 2 & 2 \\
\hline Radiation type & Mo K $\alpha$ & Mo K $\alpha$ \\
\hline$\mu\left(\mathrm{mm}^{-1}\right)$ & 0.12 & 0.11 \\
\hline$T_{\min }, T_{\max }$ & $0.810,1$ & $0.918,1$ \\
\hline $\begin{array}{l}\text { No. of measured, } \\
\text { independent and } \\
\text { observed }[I>2 \sigma(I)] \\
\text { reflections }\end{array}$ & $7869,3770,3232$ & $9555,3667,3075$ \\
\hline$R_{\text {int }}$ & 0.036 & 0.030 \\
\hline$R\left[F^{2}>2 \sigma\left(F^{2}\right)\right], \mathrm{w} R\left(F^{2}\right), S$ & $0.042,0.098,1.10$ & $0.035,0.078,0.97$ \\
\hline No. of parameters & 263 & 248 \\
\hline 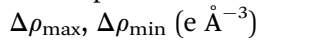 & $0.19,-0.20$ & $0.19,-0.21$ \\
\hline
\end{tabular}

Derivatives 11a and 11b were also more active against melanoma cancer cells (MDA-MB435) than the clinically useful anticancer agent doxorubicin. Although doxorubicin is considered an important drug for cancer chemotherapy, it has several clinical limitations, such as cardiotoxic effects and a high incidence of multi-drug resistance. Therefore, glycoconjugate compounds 11a, 11b, 22a and 22b can be considered promising prototypes in drug development for cancer therapy.

\section{Conclusion}

The thermal cycloaddition reaction of glycosyl azides 13a-c with 1,4-naphthoquinone (14) produced the new glyconaphthotriazoles 9a-c in moderate yields. Under the same conditions, parent compound $\mathbf{2 1}$ afforded the corresponding glyconaphthotriazoles, 11a and 11b, in moderate yields as well as the unexpected aminonaphthoquinones 22a and 22b. These carbohydrate-based naphthoquinones, 11a, 11b, 22a and 22b, derived from juglone (12) showed the best cytotoxicity profile against human cell lines HCT-116, A-549 and MDA-MB 435 when compared with the parent compounds, 9a, 9b, 10a and 10b, respectively. These data show the importance of the hydroxyl group to the pro-oxidant action of these naphthoquinone compounds. Indeed, derivatives $\mathbf{1 1 a}$ and $\mathbf{1 1 b}$ were more active than the clinically useful anticancer agent doxorubicin against melanoma cancer cells (MDA-MB435 cells). However, none of the compounds exhibited lytic effects against mouse erythrocytes.

Molecules 11a, 11b, 22a and 22b can be considered promising prototypes for cancer therapy.

\section{Experimental}

\subsection{Materials and measurements}

Melting points were determined with a Fisher-Johns - Melting Point Apparatus instrument, and the values are uncorrected. Infrared (IR) spectra were recorded on a Perkin-Elmer FT-IR 1600 spectrophotometer using $\mathrm{KBr}$ pellets. NMR spectra were recorded on a Varian Unity Plus $300 \mathrm{MHz}$ or $500 \mathrm{MHz}$ spectrometer using the specified solvents. Chemical shifts $(\delta)$ are reported in ppm, and the coupling constants $(J)$ are expressed in Hz. Column chromatography was performed with silica gel flash from Acros. The reactions were routinely monitored by thin layer chromatography (TLC) on silica gel pre-coated $\mathrm{F}_{254}$

Table 2 Cytotoxic activity expressed as the $\mathrm{IC}_{50}(\mu \mathrm{M})$ of the compounds against different cell lines ${ }^{d}$

\begin{tabular}{|c|c|c|c|c|c|}
\hline \multirow[b]{2}{*}{ Compound } & \multicolumn{3}{|c|}{ Cancer cell line $e^{a}$} & \multirow[b]{2}{*}{ Human blood leukocytes } & \multirow[b]{2}{*}{ Erythrocytes $^{c}$} \\
\hline & HCT-116 & A-549 & MDA-MB 435 & & \\
\hline $9 a$ & $>10$ & $>10$ & $>10$ & $>100$ & $>200$ \\
\hline $9 b$ & 4.85 & $>10$ & $>10$ & $>100$ & $>200$ \\
\hline $9 \mathrm{c}$ & $>10$ & $>10$ & $>10$ & $>100$ & $>200$ \\
\hline 10a & $>10$ & $>10$ & 8.9 & $>100$ & $>200$ \\
\hline $10 b$ & $>10$ & $>10$ & $>10$ & $>100$ & $>200$ \\
\hline $10 \mathrm{c}$ & $>10$ & $>10$ & $>10$ & $>100$ & $>200$ \\
\hline $11 a$ & 0.67 & 1.22 & 0.47 & $>100$ & $>200$ \\
\hline $11 b$ & 0.52 & 0.99 & 0.29 & $>100$ & $>200$ \\
\hline 12 & 1.60 & 3.7 & NT & $>100$ & $>200$ \\
\hline 14 & $>10$ & NT & NT & $>100$ & $>200$ \\
\hline $22 a$ & 1.26 & 0.77 & 5.0 & $>100$ & $>200$ \\
\hline $22 b$ & 0.43 & 1.76 & NT & $>100$ & $>200$ \\
\hline Doxorubicin $^{b}$ & 0.10 & 0.47 & 0.88 & 3.41 & $>25$ \\
\hline
\end{tabular}

${ }^{a}$ Data are presented as $\mathrm{IC}_{50}$ values $(\mu \mathrm{M})$, and $95 \%$ confidence intervals were obtained by nonlinear regression for all cell lines from three independent experiments. ${ }^{b}$ Doxorubicin was used as a positive control. Only compounds with an $\mathrm{IC}_{50}$ value lower than $5 \mathrm{mg} \mathrm{mL}^{-1}$ for at least one cell line were considered active. ${ }^{c}$ Concentration of compound that induced erythrocyte lysis. ${ }^{d}$ NT - not tested. 
Merck plates. Microanalyses were performed using a PerkinElmer Model 2400 instrument, and all values were within $\pm 0.4 \%$ of the calculated compositions.

\subsection{General procedure for the preparation of new naphthotriazoles $9 \mathrm{a}-\mathrm{c}$}

The glycosyl azides 13a-c (1.0 mmol) and 1,4-naphthoquinone (14) $(0.158 \mathrm{mg}, 1.0 \mathrm{mmol})$ were dissolved in toluene and heated at $100{ }^{\circ} \mathrm{C}$ for 24 hours. After completion of the reaction, which was monitored using TLC (eluted with hexane/EtOAc $=1 / 1$ ), the mixture was cooled, and the solvent was removed. The residual solid product was purified by column chromatography on silica gel and eluted with an increasing polarity gradient mixture of hexane and ethyl acetate $(100 \%$ to $50 \%)$ to afford compounds 9a-c.

(Methyl-5'-deoxy-2', $3^{\prime}$-O-isopropylidene- $\beta$-D-ribofuranosid-5' yl)-1H-naphtho[2,3-d][1,2,3]triazole-4,9-dione (9a). The 1,3dipolar cycloaddition reaction between naphthoquinone 12 and glycosyl azide 13a yielded glyconaphthotriazole 9a $(121.0 \mathrm{mg}$, $63 \%)$ as an orange solid: $\mathrm{mp} 225-227{ }^{\circ} \mathrm{C}$; IR $(\mathrm{KBr}) \nu\left(\mathrm{cm}^{-1}\right): 1588$ and $1686(\mathrm{C}=\mathrm{O})$.

${ }^{1} \mathrm{H}$ NMR (500.00 MHz, $\left.\mathrm{CDCl}_{3}\right) \delta: 1.30\left(\mathrm{~s}, 3 \mathrm{H}, \mathrm{CH}_{3}\right), 1.44(\mathrm{~s}, 3 \mathrm{H}$, $\left.\mathrm{CH}_{3}\right), 3.41\left(\mathrm{~s}, 3 \mathrm{H}, \mathrm{OCH}_{3}\right), 4.72-4.73\left(\mathrm{~m}, 1 \mathrm{H}, \mathrm{H}-4^{\prime}\right), 4.74(\mathrm{~d}, 1 \mathrm{H}, J$ $\left.=6.0 \mathrm{~Hz}, \mathrm{H}-2^{\prime}\right), 4.86\left(\mathrm{~d}, 1 \mathrm{H}, J=6.0 \mathrm{~Hz}, \mathrm{H}-3^{\prime}\right), 5.01(\mathrm{dd}, 2 \mathrm{H}, J=$ 7.5 and $1.0 \mathrm{~Hz}, \mathrm{H}-5^{\prime} \mathrm{a}$ and $\left.\mathrm{H}-5^{\prime} \mathrm{b}\right), 5.02\left(\mathrm{~s}, 1 \mathrm{H}, \mathrm{H}-1^{\prime}\right), 7.82(\mathrm{td}, 1 \mathrm{H}, J$ $=7.5$ and $1.5 \mathrm{~Hz}, \mathrm{H}-7), 7.86(\mathrm{td}, 1 \mathrm{H}, J=7.5$ and $1.5 \mathrm{~Hz}, \mathrm{H}-6), 8.24$ (dd, $1 \mathrm{H}, J=7.5$ and $1.5 \mathrm{~Hz}, \mathrm{H}-8), 8.34$ (dd, $1 \mathrm{H}, J=7.5$ and 1.5 $\mathrm{Hz}, \mathrm{H}-5) \mathrm{ppm}$.

${ }^{13} \mathrm{C}$ NMR $\left(125.0 \mathrm{MHz}, \mathrm{CDCl}_{3}\right) \delta: 25.1\left(\mathrm{CH}_{3}\right), 26.5\left(\underline{\mathrm{CH}}_{3}\right), 53.2$ $\left(\mathrm{C}-5^{\prime}\right), 55.9\left(\mathrm{OCH}_{3}\right), 81.8\left(\mathrm{C}-3^{\prime}\right), 84.6\left(\mathrm{C}-4^{\prime}\right), 85.3\left(\mathrm{C}-2^{\prime}\right), 110.4(\mathrm{C}-$ 1'), 113.1 (-OCO-), 127.5 (C-8), 128.5 (C-5), 132.8 (C-8a), 133.5 (C-4a), 133.6 (C-9a), 134.5 (C-7), 135.4 (C-6), 145.7 (C-3a), 175.6 (C-9), 176.7 (C-4) ppm. Anal. calc. for $\mathrm{C}_{19} \mathrm{H}_{19} \mathrm{~N}_{3} \mathrm{O}_{6}$ : C, 59.22; $\mathrm{H}$, 4.97; N, 10.90. Found: C, 59.05; H, 5.29; N, 10.79\%.

1-(6'-Deoxy-1' $, 2^{\prime}: 3^{\prime}, 4^{\prime}$-di-O-isopropylidene-D-galactopyranos$6^{\prime}$-yl)-1H-naphtho[2,3-d][1,2,3]triazole-4,9-dione (9b). The 1,3dipolar cycloaddition reaction between naphthoquinone 12 and glycosyl azide 13b yielded glyconaphthotriazole $9 \mathrm{~b}(126.0 \mathrm{mg}$, $57 \%$ ) as a light yellow solid: $\operatorname{mp} 160-162{ }^{\circ} \mathrm{C}$; IR $(\mathrm{KBr}) \nu\left(\mathrm{cm}^{-1}\right)$ : 1689 and $1593(\mathrm{C}=\mathrm{O}) .{ }^{1} \mathrm{H}$ NMR $\left(300.00 \mathrm{MHz} \mathrm{CDCl}_{3}\right) \delta: 1.22$ (s, $\left.3 \mathrm{H}, \mathrm{CH}_{3}\right), 1.35$ (s, 3H, $\left.\underline{\mathrm{H}}_{3}\right), 1.38\left(\mathrm{~s}, 3 \mathrm{H}, \mathrm{CH}_{3}\right), 1.57$ (s, 3H, $\left.\mathrm{CH}_{3}\right)$, $4.31\left(\mathrm{dd}, 1 \mathrm{H}, J=5.0\right.$ and $\left.2.7 \mathrm{~Hz}, \mathrm{H}-2^{\prime}\right), 4.36(\mathrm{dd}, 1 \mathrm{H}, J=7.8$ and $\left.2.0 \mathrm{~Hz}, \mathrm{H}-3^{\prime}\right)$, 4.46-4.49 (m, $\left.1 \mathrm{H}, \mathrm{H}-5^{\prime}\right), 4.68$ (dd, $1 \mathrm{H}, J=7.8$ and $2.6 \mathrm{~Hz}, \mathrm{H}-4^{\prime}$ ), 4.82 (dd, $1 \mathrm{H}, J=13.9$ and $3.4 \mathrm{~Hz}, \mathrm{H}-6^{\prime} \mathrm{a}$ ), 5.32 (dd, $1 \mathrm{H}, J=13.9$ and $\left.9.6 \mathrm{~Hz}, \mathrm{H}-6^{\prime} \mathrm{b}\right), 5.40\left(\mathrm{~d}, 1 \mathrm{H}, J=5.0 \mathrm{~Hz}, \mathrm{H}-1^{\prime}\right)$, $7.80(\mathrm{td}, 1 \mathrm{H}, J=7.5$ and $1.5 \mathrm{~Hz}, \mathrm{H}-7), 7.85(\mathrm{td}, 1 \mathrm{H}, J=7.5$ and 1.5 $\mathrm{Hz}, \mathrm{H}-6), 8.24$ (dd, $1 \mathrm{H}, J=7.6$ and $1.2 \mathrm{~Hz}, \mathrm{H}-8$ ), 8.34 (dd, $1 \mathrm{H}, J=$ 7.6 and $1.2 \mathrm{~Hz}, \mathrm{H}-5)$ ppm.

${ }^{13} \mathrm{C}$ NMR (75.0 MHz, $\left.\mathrm{CDCl}_{3}\right) \delta: 24.8\left(\underline{\mathrm{CH}}_{3}\right), 24.9\left(\underline{\mathrm{CH}}_{3}\right), 25.8$ $\left(\underline{\mathrm{CH}}_{3}\right), 26.2\left(\underline{\mathrm{CH}}_{3}\right), 50.7\left(\mathrm{C}-6^{\prime}\right), 67.2\left(\mathrm{C}-5^{\prime}\right), 70.4\left(\mathrm{C}-2^{\prime}\right), 71.2\left(\mathrm{C}-4^{\prime}\right)$, $71.4\left(\mathrm{C}-3^{\prime}\right), 96.3$ (C-1'), 109.1 (-OCOO-), 110.4 (-OCEO-), 127.4 (C5), 127.9 (C-8), 133.0 (C-8a), 133.6 (C-4a), 134.3 (C-7), 134.4 (C9a), 135.2 (C-6), 145.6 (C-3a), 175.5 (C-9), 176.9 (C-4) ppm. Anal. calc. for $\mathrm{C}_{22} \mathrm{H}_{23} \mathrm{~N}_{3} \mathrm{O}_{7}: \mathrm{C}, 59.86 ; \mathrm{H}, 5.25 ; \mathrm{N}, 9.52$. Found: $\mathrm{C}$, 59.32; H, 5.63; N, 9.25\%.
1-(5'-Deoxy-1', $\mathbf{2}^{\prime}$ - $O$-isopropylidene-D-xylofuranos-5'-yl)-1Hnaphtho[2,3-d][1,2,3]triazole-4,9-dione (9c). The 1,3-dipolar cycloaddition reaction between naphthoquinone 12 and glycosyl azide 13c yielded glyconaphthotriazole 9c $(90.0 \mathrm{mg}$, 48\%) as a light yellow solid: $\operatorname{mp} 240-243{ }^{\circ} \mathrm{C}$; IR $(\mathrm{KBr}) \nu\left(\mathrm{cm}^{-1}\right)$ : 1687 and $1592(\mathrm{C}=\mathrm{O}) .{ }^{1} \mathrm{H}$ NMR (500.00 MHz, DMSO) $\delta: 1.21$ (s, $\left.3 \mathrm{H}, \mathrm{CH}_{3}\right), 1.31\left(\mathrm{~s}, 3 \mathrm{H}, \mathrm{CH}_{3}\right), 4.18\left(\mathrm{~d}, 1 \mathrm{H}, J=2.7 \mathrm{~Hz}, \mathrm{H}-3^{\prime}\right), 4.50$ (d, $\left.1 \mathrm{H}, J=3.6 \mathrm{~Hz}, \mathrm{H}-2^{\prime}\right), 4.61-4.64\left(\mathrm{~m}, 1 \mathrm{H}, \mathrm{H}-4^{\prime}\right), 5.00-5.01(\mathrm{~m}, 2 \mathrm{H}$, $\mathrm{H}-5^{\prime} \mathrm{a}$ and $\left.\mathrm{H}-5^{\prime} \mathrm{b}\right), 5.88$ (d, $\left.1 \mathrm{H}, J=3.6 \mathrm{~Hz}, \mathrm{H}-1^{\prime}\right), 7.92(\mathrm{td}, 1 \mathrm{H}, J=$ 7.5 and $1.5 \mathrm{~Hz}, \mathrm{H}-7), 7.95$ (td, $1 \mathrm{H}, J=7.5$ and $1.5 \mathrm{~Hz}, \mathrm{H}-6), 8.17$ (dd, $1 \mathrm{H}, J=7.5$ and $1.5 \mathrm{~Hz}, \mathrm{H}-8), 8.19$ (dd, $1 \mathrm{H}, J=6.5$ and 1.5 $\mathrm{Hz}, \mathrm{H}-5$ ) ppm. ${ }^{13} \mathrm{C}$ NMR (125.0 MHz, DMSO) $\delta: 26.1\left(\underline{\mathrm{CH}}_{3}\right), 26.7$ $\left(\underline{\mathrm{CH}}_{3}\right), 49.4\left(\mathrm{C}-5^{\prime}\right), 73.8\left(\mathrm{C}-3^{\prime}\right), 78.5\left(\mathrm{C}-4^{\prime}\right), 85.1\left(\mathrm{C}-2^{\prime}\right), 104.5\left(\mathrm{C}-1^{\prime}\right)$, 110.9 (-OCOO-), 126.8 (C-5), 126.9 (C-8), 132.9 (C-8a), 133.1 (C4a), 134.3 (C-9a), 134.5 (C-7), 135.1 (C-6), 144.8 (C-3a), 175.1 (C-9), 176.8 (C-4) ppm. Anal. calc. for $\mathrm{C}_{18} \mathrm{H}_{17} \mathrm{~N}_{3} \mathrm{O}_{6}$ : C, 58.22; $\mathrm{H}$, 4.61; N, 11.32. Found: C, 58.61; H, 4.35; N, 11.52\%.

\subsection{General procedure for the preparation of new naphthoquinone derivatives 11a, 11b, 22a and 22b}

The glycosyl azides 13a and 13b $(1.0 \mathrm{mmol})$ and juglone 12 $(0.174 \mathrm{mg}, 1.0 \mathrm{mmol})$ were dissolved in toluene and heated at $100{ }^{\circ} \mathrm{C}$ for 24 hours. The reaction mixture was concentrated under reduced pressure and the resulting residue was purified by column chromatography using silica gel and eluted with an increasing polarity gradient mixture of hexane and ethyl acetate $(100 \%$ to $70 \%)$ to give the desired compounds $11 \mathrm{a}$ and $\mathbf{1 1 b}$ and the unexpected aminoquinones $\mathbf{2 2 a}$ and $\mathbf{2 2 b}$.

5-Hydroxy-(methyl-5' -deoxy-2', $3^{\prime}$ - $O$-isopropylidene- $\beta$-D-ribofuranosid- $5^{\prime}$-yl)-1H-nafto[2,3- $\left.d\right][1,2,3]$ triazole-4,9-dione (11a) and 5 -hydroxy-2-(methyl-5'-deoxy- $2^{\prime}, 3^{\prime}$ - $O$-isopropylidene- $\beta$-Dribofuranosid-5'-yl)-amino-1,4-naphthoquinone (22a). The 1,3dipolar cycloaddition reaction between juglone $\mathbf{1 2}$ and glycosyl azide 13a gave glyconaphthotriazole 11a (136.0 mg, 68\%) and amino compound 22a (5.6 mg, 3\%).

The compound 11a was obtained as a yellow solid: $\mathrm{mp} 144-$ $147{ }^{\circ} \mathrm{C}$; IR $(\mathrm{KBr}) \nu\left(\mathrm{cm}^{-1}\right): 3434(\mathrm{OH}), 1649(\mathrm{C}=\mathrm{O}), 1449(\mathrm{C}=\mathrm{C})$. ${ }^{1} \mathrm{H}$ NMR (500.00 MHz, $\left.\mathrm{CDCl}_{3}\right) \delta: 1.31\left(\mathrm{~s}, 3 \mathrm{H}, \mathrm{CH}_{3}\right), 1.45(\mathrm{~s}, 3 \mathrm{H}$, $\left.\mathrm{CH}_{3}\right), 3.41\left(\mathrm{~s}, 3 \mathrm{H}, \mathrm{OCH}_{3}\right), 4.70-4.72\left(\mathrm{~m}, 1 \mathrm{H}, \mathrm{H}-4^{\prime}\right), 4.72(\mathrm{~d}, 1 \mathrm{H}, J$ $\left.=6.0 \mathrm{~Hz}, \mathrm{H}-2^{\prime}\right), 4.85\left(\mathrm{~d}, 1 \mathrm{H}, J=6.0 \mathrm{~Hz}, \mathrm{H}-3^{\prime}\right), 4.98(\mathrm{dd}, 2 \mathrm{H}, J=$ 7.5 and $2.5 \mathrm{~Hz}, \mathrm{H}-5^{\prime} \mathrm{a}$ and $\mathrm{H}-5^{\prime} \mathrm{b}$ ), 5.02 (s, $\left.1 \mathrm{H}, \mathrm{H}-1^{\prime}\right), 7.38$ (dd, $1 \mathrm{H}$, $J=8.5$ and $1.0 \mathrm{~Hz}, \mathrm{H}-6), 7.68(\mathrm{dd}, 1 \mathrm{H}, J=8.5$ and $7.5 \mathrm{~Hz}, \mathrm{H}-7)$, $7.80(\mathrm{dd}, 1 \mathrm{H}, J=7.5$ and $1.0 \mathrm{~Hz}, \mathrm{H}-8), 12.31$ (s, $1 \mathrm{H}, \mathrm{OH}) \mathrm{ppm}$.

${ }^{13} \mathrm{C} / \mathrm{APT}$ NMR $\left(125.0 \mathrm{MHz}, \mathrm{CDCl}_{3}\right) \delta: 25.1\left(\mathrm{CH}_{3}\right), 26.5\left(\underline{\mathrm{CH}}_{3}\right)$, $53.3\left(\mathrm{C}-5^{\prime}\right), 56.0\left(\mathrm{OCH}_{3}\right), 81.8\left(\mathrm{C}-4^{\prime}\right), 84.6\left(\mathrm{C}-2^{\prime}\right), 85.3\left(\mathrm{C}-3^{\prime}\right), 110.4$ (C-1'), 113.1 (-OCO-), 115.5 (C-4a), 120.8 (C-8), 126.9 (C-6), 133.2 (C-8a), 133.9 (C-9a), 136.9 (C-7), 145.5 (C-3a), 163.6 (C-5), 174.8 (C-9), 182.7 (C-4) ppm. Anal. calc. for $\mathrm{C}_{19} \mathrm{H}_{19} \mathrm{~N}_{3} \mathrm{O}_{7}$ : C, 56.86; $\mathrm{H}$, 4.77 ; N, 10.47. Found: C, 58.04; H, 5.25; N, 9.05\%.

The compound 22a was obtained as a red solid: mp 128-130 ${ }^{\circ} \mathrm{C}$; IR $(\mathrm{KBr}) \nu\left(\mathrm{cm}^{-1}\right): 3401(\mathrm{OH}), 3263(\mathrm{~N}-\mathrm{H}) ; 1623,1592(\mathrm{C}=\mathrm{O})$, $1468(\mathrm{C}=\mathrm{C}) .{ }^{1} \mathrm{H}$ NMR (500.00 MHz, $\left.\mathrm{CDCl}_{3}\right) \delta: 1.32\left(\mathrm{~s}, 3 \mathrm{H}, \mathrm{CH}_{3}\right)$, 1.50 (s, 3H, $\underline{\mathrm{CH}}_{3}$ ), 3.29-3.34 (m, 2H, H-5' a and $\left.\mathrm{H}-5^{\prime} \mathrm{b}\right), 3.41$ (s, $\left.3 \mathrm{H}, \mathrm{OC}_{3}\right), 4.49-4.51\left(\mathrm{~m}, 1 \mathrm{H}, \mathrm{H}-4^{\prime}\right), 4.63(\mathrm{dd}, 1 \mathrm{H}, J=6.0$ and 1.0 $\mathrm{Hz}, \mathrm{H}-3^{\prime}$ ), 4.66 (d, $\left.1 \mathrm{H}, J=6.0 \mathrm{~Hz}, \mathrm{H}-2^{\prime}\right), 5.05$ (s, 1H, H-1'), 5.64 (s, $1 \mathrm{H}, \mathrm{H}-3), 6.66-6.68(\mathrm{~m}, 1 \mathrm{H}, \mathrm{N}-\underline{\mathrm{H}}), 7.25(\mathrm{dd}, 1 \mathrm{H}, J=8.5$ and 1.0 
$\mathrm{Hz}, \mathrm{H}-6), 7.47$ (dd, $1 \mathrm{H}, J=8.5$ and $7.5 \mathrm{~Hz}, \mathrm{H}-7$ ), 7.59 (dd, $1 \mathrm{H}, J=$ 7.5 and $1.0 \mathrm{~Hz}, \mathrm{H}-8), 12.98(\mathrm{~s}, 1 \mathrm{H}, \mathrm{OH}) \mathrm{ppm} .{ }^{13} \mathrm{C} / \mathrm{APT}$ NMR $\left(125.0 \mathrm{MHz}, \mathrm{CDCl}_{3}\right) \delta$ ppm: $25.1\left(\underline{\mathrm{CH}}_{3}\right), 26.6\left(\underline{\mathrm{CH}}_{3}\right), 45.6\left(\mathrm{C}-5^{\prime}\right)$, $55.7\left(\mathrm{OCH}_{3}\right), 82.3\left(\mathrm{C}-3^{\prime}\right), 84.5\left(\mathrm{C}-4^{\prime}\right), 85.4\left(\mathrm{C}-2^{\prime}\right), 100.5(\mathrm{C}-3), 109.8$ (C-1'), 113.1 (-OCO-), 115.0 (C-4a), 119.2 (C-8), 126.1 (C-6), 130.7 (C-8a), 134.2 (C-7), 149.0 (C-2), 161.3 (C-5), 181.1 (C-1), 189.2 (C4) ppm. Anal. calc. for $\mathrm{C}_{19} \mathrm{H}_{21} \mathrm{NO}_{7}: \mathrm{C}, 60.79 ; \mathrm{H}, 5.64 ; \mathrm{N}, 3.73$. Found: C, 61.61; H, 6.00; N, 3.21\%.

5-Hydroxy-1-(6'-deoxy-1 $1^{\prime}, 2^{\prime}: 3^{\prime}, 4^{\prime}$-di-O-isopropylidene-D-galactopyranos- $6^{\prime}$-yl)-1H-nafto[2,3-d][1,2,3]triazole-4,9-dione (11b) and 5-hydroxy-2-(6'-deoxy-1 $\mathbf{1}^{\prime}, 2^{\prime}: 3^{\prime}, 4^{\prime}$-di-O-isopropylidene-D-galactopyranos-6 $\mathbf{6}^{\prime}$-yl)-amino-1,4-naphthoquinone (22b). The 1,3dipolar cycloaddition reaction between juglone $\mathbf{1 2}$ and glycosyl azide 13b gave glyconaphthotriazole $11 b(64.0 \mathrm{mg}, 28 \%)$ and amino compound $22 \mathrm{~b}$ ( $4.3 \mathrm{mg}, 2 \%)$.

The compound 11b was obtained a yellow solid: $\mathrm{mp}$ 160$162{ }^{\circ} \mathrm{C}$; IR $(\mathrm{KBr}) \nu\left(\mathrm{cm}^{-1}\right): 3416(\mathrm{OH}), 1654(\mathrm{C}=\mathrm{O}), 1453(\mathrm{C}=\mathrm{C})$. ${ }^{1} \mathrm{H}$ NMR (300.00 MHz, $\left.\mathrm{CDCl}_{3}\right) \delta: 1.23\left(\mathrm{~s}, 3 \mathrm{H}, \mathrm{CH}_{3}\right), 1.36(\mathrm{~s}, 3 \mathrm{H}$, $\left.\mathrm{CH}_{3}\right), 1.38\left(\mathrm{~s}, 3 \mathrm{H}, \mathrm{CH}_{3}\right), 1.57\left(\mathrm{~s}, 3 \mathrm{H}, \mathrm{CH}_{3}\right), 4.32$ (dd, $1 \mathrm{H}, J=5.0$ and $2.5 \mathrm{~Hz}, \mathrm{H}-2^{\prime}$ ), 4.36 (dd, $1 \mathrm{H}, J=7.5$ and $\left.2.0 \mathrm{~Hz}, \mathrm{H}-4^{\prime}\right), 4.44-$ 4.47 (m, $\left.1 \mathrm{H}, \mathrm{H}-5^{\prime}\right), 4.69$ (dd, $1 \mathrm{H}, J=7.5$ and $\left.2.5 \mathrm{~Hz}, \mathrm{H}-3^{\prime}\right), 4.81$ (dd, $1 \mathrm{H}, J=14.0$ and $3.5 \mathrm{~Hz}, \mathrm{H}-6^{\prime} \mathrm{a}$ ), 5.31 (dd, $1 \mathrm{H}, J=14.0$ and $10.0 \mathrm{~Hz}, \mathrm{H}-6^{\prime} \mathrm{b}$ ), 5.39 (d, 1H, $\left.J=5.0 \mathrm{~Hz}, \mathrm{H}-1^{\prime}\right), 7.36$ (dd, $1 \mathrm{H}, J=$ 8.5 and $1.5 \mathrm{~Hz}, \mathrm{H}-6), 7.66$ (dd, $1 \mathrm{H}, J=8.5$ and 7.5, H-7), 7.77 (dd, $1 \mathrm{H}, J=7.5$ and $1.0 \mathrm{~Hz}, \mathrm{H}-8), 12.34(\mathrm{~s}, 1 \mathrm{H}, \mathrm{OH}) \mathrm{ppm} .{ }^{13} \mathrm{C} / \mathrm{APT}$ NMR (75.0 MHz, $\left.\mathrm{CDCl}_{3}\right) \delta: 24.9\left(\underline{\mathrm{CH}}_{3}\right), 25.0\left(\underline{\mathrm{CH}}_{3}\right), 25.8\left(\underline{\mathrm{CH}}_{3}\right)$, $26.2\left(\mathrm{CH}_{3}\right), 50.8\left(\mathrm{C}-6^{\prime}\right), 67.1\left(\mathrm{C}-5^{\prime}\right), 70.4\left(\mathrm{C}-2^{\prime}\right), 71.2\left(\mathrm{C}-3^{\prime}\right), 71.4(\mathrm{C}-$ $\left.4^{\prime}\right), 96.3$ (C-1'), 109.1 (-Oㅡㅇ-), 110.5 (-Oㅡㅇ-), 115.6 (C-4a), 120.5 (C-8), 126.6 (C-6), 133.4 (C-8a), 134.4 (C-9a), 136.7 (C-7), 145.2 (C3a), 163.5 (C-5), 174.7 (C-9), 183.0 (C-4) ppm. Anal. calc. for $\mathrm{C}_{22} \mathrm{H}_{23} \mathrm{~N}_{3} \mathrm{O}_{8}$ : C, 57.76; H, 5.07; N, 9.19. Found: C, 57.99; H, 5.34; $\mathrm{N}, 8.78 \%$.

The compound 22b was obtained as a red solid: mp 203-205 ${ }^{\circ} \mathrm{C}$; IR $(\mathrm{KBr}) \nu\left(\mathrm{cm}^{-1}\right): 3400(\mathrm{OH}), 3341(\mathrm{~N}-\mathrm{H}), 1615(\mathrm{C}=\mathrm{O}), 1469$ $(\mathrm{C}=\mathrm{C}) .{ }^{1} \mathrm{H}$ NMR $\left(300.00 \mathrm{MHz}, \mathrm{CDCl}_{3}\right) \delta: 1.33\left(\mathrm{~s}, 3 \mathrm{H}, \mathrm{CH}_{3}\right), 1.37$ (s, 3H, $\left.\mathrm{CH}_{3}\right), 1.49\left(\mathrm{~s}, 3 \mathrm{H}, \mathrm{CH}_{3}\right), 1.52\left(\mathrm{~s}, 3 \mathrm{H}, \mathrm{CH}_{3}\right), 3.44-3.48(\mathrm{~m}$, $2 \mathrm{H}, \mathrm{H}-6^{\prime} \mathrm{a}$ and $\left.\mathrm{H}-6^{\prime} \mathrm{b}\right), 4.00-4.05\left(\mathrm{~m}, 1 \mathrm{H}, \mathrm{H}-5^{\prime}\right), 4.25(\mathrm{dd}, 1 \mathrm{H}, J=$ 7.8 and $\left.1.8 \mathrm{~Hz}, \mathrm{H}-4^{\prime}\right), 4.35\left(\mathrm{dd}, 1 \mathrm{H}, J=5.1\right.$ and $\left.2.4 \mathrm{~Hz}, \mathrm{H}-2^{\prime}\right), 4.65$ (dd, $1 \mathrm{H}, J=7.8$ and $\left.2.4 \mathrm{~Hz}, \mathrm{H}-3^{\prime}\right), 5.55\left(\mathrm{~d}, 1 \mathrm{H}, J=5.1 \mathrm{~Hz}, \mathrm{H}-1^{\prime}\right)$, 5.67 (s, 1H, H-3), 6.52-6.56 (m, 1H, N- $\underline{\mathrm{H}}$ ), 7.23 (dd, $1 \mathrm{H}, J=8.4$ and $1.2 \mathrm{~Hz}, \mathrm{H}-6$ ), 7.46 (dd, $1 \mathrm{H}, J=8.4$ and $7.5 \mathrm{~Hz}, \mathrm{H}-7$ ), 7.59 (dd, $1 \mathrm{H}, J=7.5$ and $1.2 \mathrm{~Hz}, \mathrm{H}-8), 13.05$ (s, $1 \mathrm{H}, \mathrm{OH}) \mathrm{ppm} .{ }^{13} \mathrm{C} / \mathrm{APT}$ NMR (75.0 MHz, $\left.\mathrm{CDCl}_{3}\right) \delta: 24.5\left(\underline{\mathrm{CH}}_{3}\right), 25.0\left(\underline{\mathrm{CH}}_{3}\right), 26.1\left(\underline{\mathrm{CH}}_{3}\right)$, $26.2\left(\mathrm{CH}_{3}\right), 43.3\left(\mathrm{C}^{\prime} 6^{\prime}\right), 64.9\left(\mathrm{C}-5^{\prime}\right), 70.5\left(\mathrm{C}-3^{\prime}\right), 70.6\left(\mathrm{C}-4^{\prime}\right), 71.9(\mathrm{C}-$ 2'), 96.5 (C-1'), 99.9 (C-3), 109.0 (-OCEO-), 110.0 (-OCOO-), 115.1 (C-4a), 119.2 (C-8), 125.9 (C-6), 130.7 (C-8a), 134.0 (C-7), 149.1 (C2), 161, 2 (C-5), 181.0 (C-1), 189.1 (C-4) ppm. Anal. calc. for $\mathrm{C}_{22} \mathrm{H}_{25} \mathrm{NO}_{8}$ : C, 61.25; H, 5.84; N, 3.25. Found: C, 61.97; H, 6.18; $\mathrm{N}, 3.31 \%$.

\section{X-ray determination}

X-ray diffraction was performed using an Oxford Diffraction Xcalibur Atlas Gemini ultra Diffractometer at $150 \mathrm{~K}$ with Mo-K $\alpha$ radiation. The collection and reduction of the data were performed using the CrysAlisPro software. The structures (Table 1) were solved by direct methods and refined using full-matrix least squares on $F^{2}$ with the SHELX-97 software package. ${ }^{23}$ The CCDC reference numbers for 11a and 22a are 1055525 and 1055524, respectively. $\dagger$

\section{Biology}

\subsection{Cytotoxicity against cancer cell lines}

The compounds $(0.15-20 \mu \mathrm{M})$ were tested for cytotoxic activity against cell lines HCT-116 (human colorectal carcinoma, ATCC \# CCL-247), A-549 (human lung adenocarcinoma, ATCC \# CCL185) and MDA-MB435 (human melanoma, ATCC \# HTB-129) as well as against freshly prepared human blood leukocytes and erythrocytes. All cell lines were maintained in DMEM medium supplemented with $10 \%$ fetal bovine serum, $2 \mathrm{mM}$ glutamine, $100 \mathrm{U} \mathrm{mL}^{-1}$ penicillin, and $100 \mathrm{mg} \mathrm{mL}^{-1}$ streptomycin at $37^{\circ} \mathrm{C}$ in an atmosphere containing $5 \% \mathrm{CO}_{2}$. Each compound was dissolved with DMSO and diluted with the cell culture medium to obtain a concentration of $100 \mu \mathrm{M}$, which was then incubated with the cells for 72 hours. The negative control received the same amount of DMSO (0.005\% at the highest concentration). Doxorubicin was used as a positive control. Cell viability was determined by the reduction of the yellow dye 3-(4,5-dimethyl-2thiazol)-2,5-diphenyl-2 $H$-tetrazolium bromide (MTT) to a blue formazan product after 3 hours of incubation, as described by Denizot (1986). ${ }^{24}$

\subsection{Cell membrane disruption}

Cytotoxicity testing was performed as described previously ${ }^{25}$ in 96-well plates using a $2 \%$ mouse erythrocyte suspension in $0.85 \% \mathrm{NaCl}$ containing $10 \mathrm{mM} \mathrm{CaCl}_{2}$. The compounds, which were diluted as mentioned above, were tested at concentration of $200 \mu \mathrm{M}$. After incubation at room temperature for $30 \mathrm{~min}$ and centrifugation, the supernatant was removed, and the liberated hemoglobin was measured spectrophotometrically at $540 \mathrm{~nm}$. DMSO was used as a negative control and Triton X-100 (1\%) was used as a positive control.

\section{Acknowledgements}

This work was supported by the Brazilian agency FAPERJPRONEX. Fellowships granted to UFF, by FAPERJ, CAPES, and CNPq-PIBIC are gratefully acknowledged. We would like to thank the LabCri/UFMG for the use of the X-ray facilities.

\section{References}

1 U. Galm, M. H. Hager, S. G. V. Lanen, J. J. J. S. Thorson and B. Shen, Chem. Rev., 2005, 105, 739.

2 J.-L. Yu, Q.-P. Wu, Q.-S. Zhang, Y.-H. Liu, Y.-Z. Li and Z.-M. Zhou, Bioorg. Med. Chem. Lett., 2010, 20, 240.

3 M. N. da Silva, V. F. Ferreira and M. C. B. V. de Souza, Quim. Nova, 2003, 26, 407.

4 V. K. Tiwaria, R. C. Mishra, A. Sharma and R. P. Tripathi, Mini-Rev. Med. Chem., 2012, 12, 1497.

5 V. R. Campos, E. A. dos Santos, V. F. Ferreira, R. C. Montenegro, M. C. B. V. de Souza, L. V. Costa-Lotufo, 
M. O. de Moraes, A. K. P. Regufe, A. K. Jordão, A. C. Pinto, J. A. L. C. Resende and A. C. Cunha, RSC Adv., 2012, 2, 11438-11448.

6 C. Temperini, M. Cirilli, M. Aschi and G. Ughetto, Bioorg. Med. Chem., 2005, 13, 1673.

7 Z. S. Saify, N. Mushtaq, F. Noor, S. Takween and M. Arif, Pak. J. Pharm. Sci., 1999, 12, 21.

8 Y. Zhao, E. B. Butler and M. Tan, Cell Death Dis., 2013, 4, e532.

9 M. A. Castro, A. M. Gamito, V. Tangarife-Castaño, V. RoaLinares, J. Ma, M. del Corral, A. C. Mesa-Arango, L. Betancur-Galvis, A. M. Francesch and A. San Feliciano, RSC Adv., 2015, 5, 1244.

10 J. S. Kim, H.-K. Rhee, H. J. Park, S. K. Lee, C.-O. Lee and H.-Y. P. Choo, Bioorg. Med. Chem., 2008, 16, 4545-4550.

11 A. C. Cunha, J. M. Figueiredo, J. L. M. Tributino, A. L. P. Miranda, H. C. Castro, R. B. Zingali, C. A. M. Fraga, M. C. B. V. de Souza, V. F. Ferreira and E. J. Barreiro, Bioorg. Med. Chem., 2003, 11, 2051.

12 A. K. Jordão, V. F. Ferreira, E. S. Lima, M. C. B. V. de Souza, E. C. L. Carlos, H. C. Castro, R. B. Geraldo, C. R. Rodrigues, M. C. B. Almeida and A. C. Cunha, Bioorg. Med. Chem., 2009, 17, 3713.

13 R. Menegatti, A. C. Cunha, V. F. Ferreira, E. F. R. Perreira, A. El-Nabawi, A. T. Eldefrawi, E. X. Albuquerque, G. Neves, S. M. K. Rates, C. A. M. Fraga and E. J. Barreiro, Bioorg. Med. Chem., 2003, 11, 4807.

14 M. S. Costa, N. Boechat, E. A. Rangel, F. C. da Silva, A. M. T. de Souza, C. R. Rodrigues, H. C. Castro, I. N. Junior, M. C. S. Lourenço, S. M. S. V. Wardell and V. F. Ferreira, Bioorg. Med. Chem., 2006, 14, 8644.
15 V. R. Campos, P. A. Abreu, H. C. Castro, C. R. Rodrigues, A. K. Jordão, V. F. Ferreira, M. C. B. V. de Souza, F. C. Santos, L. A. Moura, T. S. Domingos, C. Carvalho, E. F. Sanchez, A. L. Fuly and A. C. Cunha, Bioorg. Med. Chem., 2009, 17, 7429.

16 S. G. Agalave, S. R. Maujan and V. S. Pore, Chem.-Asian J., 2011, 6, 2696-2718.

17 C. F. J. Franco, A. K. Jordão, V. F. Ferreira, A. C. Pinto, M. C. B. V. de Souza, J. A. L. C. Resende and A. C. Cunha, J. Braz. Chem. Soc., 2011, 22, 187.

18 K. Murakami, M. Haneda, S. Iwata and M. Yoshino, Toxicol. In Vitro, 2010, 24, 905.

19 B. S. Moon, A. Y. Shim, K. C. Lee, H. J. Lee, B. S. Lee, G. I. An, S. D. Yang, D. Y. Chi, C. W. Choi, S. M. Lim and K. S. Chun, Bull. Korean Chem. Soc., 2005, 26, 1865.

20 S. B. Ferreira, A. C. R. Sodero, M. F. C. Cardoso, E. S. Lima, C. R. Kaiser, F. P. Silva Jr and V. F. Ferreira, J. Med. Chem., 2010, 53, 2364.

21 D. R. Rocha, A. C. G. Souza, J. A. L. C. Resende, W. C. Santos, E. A. Santos, C. Pessoa, M. O. Moraes, L. V. Costa-Lotufo, R. C. Montenegro and V. F. Ferreira, Org. Biomol. Chem., 2011, 9, 4315.

22 E. Pérez-Sacau, R. G. Díaz-Peñate, A. Estévez-Braun, A. G. Ravelo, J. M. García-Castellano, L. Pardo and M. Campillo, J. Med. Chem., 2007, 50, 696.

23 G. M. Sheldrick, Acta Crystallogr., Sect. D: Biol. Crystallogr., 2010, 66, 479.

24 F. Denizot and R. Lang, J. Immunol. Methods, 1986, 89, 271. 25 P. Sharma and J. D. Sharma, J. Ethnopharmacol., 2001, 74, 239. 